\title{
Ethnologies
}

\section{Ann McElroy. Nunavut Generations: Change and Continuity in Canadian Inuit Communities. (Waveland Press, 2008. ISBN: -10: 1577664892)}

\section{Nicholas Hartmann}

Volume 33, numéro 2, 2011

URI : https://id.erudit.org/iderudit/1015040ar

DOI : https://doi.org/10.7202/1015040ar

Aller au sommaire du numéro

Éditeur(s)

Association Canadienne d'Ethnologie et de Folklore

ISSN

1481-5974 (imprimé)

1708-0401 (numérique)

Découvrir la revue

Citer ce compte rendu

Hartmann, N. (2011). Compte rendu de [Ann McElroy. Nunavut Generations:

Change and Continuity in Canadian Inuit Communities. (Waveland Press, 2008.

ISBN: -10: 1577664892)]. Ethnologies, 33(2), 273-276.

https://doi.org/10.7202/1015040ar d'utilisation que vous pouvez consulter en ligne.

https://apropos.erudit.org/fr/usagers/politique-dutilisation/ 
Montréal. L'absence d'une carte géographique de la métropole est notable. Or, comment l'enracinement des maisons de jeu évolue-t-il sur le territoire montréalais - lui qui s'agrandit par le biais de successives fusions municipales - entre 1892 et 1970 ? Le géoréférencement des maisons de jeu aurait permis, selon nous, une exploration plus soutenue des raisons pour lesquelles le vice et la corruption n'infiltrent pas tout le territoire montréalais de l'époque. Enfin, il est surprenant que l'auteure omette de mentionner la télésérie Montréal, ville ouverte, même si cette formule connue se retrouve au sein du livre. Cette télésérie diffusée au Québec en 1992 raconte l’histoire de la lutte menée par Jean Drapeau et Pacifique Plante contre la pègre montréalaise.

Néanmoins, le retour historique de Brodeur permet de mieux éclairer les récents scandales de corruption à la Ville de Montréal ainsi que les débats sur la gestion étatique du jeu.

\section{Ann McElroy. Nunavut Generations: Change and Continuity in Canadian Inuit Communities}

(Waveland Press, 2008. ISBN: -10: 1577664892)

\section{Nicholas Hartmann Memorial University of Newfoundland}

At the beginning of the first chapter of this book, Ann McElroy includes a quote from Inuit leader Jose Kusugak, who said, "Nunavut offers a lesson to the broader global community. And that lesson is about the resilience of the human spirit." Resilience in the face of sociocultural, economic and other issues is indeed a core part of the Nunavut experience, and McElroy's book discusses such an idea through a cultural history of those who call, or have called, home Canada's most recent territory .

Using a mixture of oral history, geography and folklore to describe how Inuit generations change over time, McElroy's book is broad in its 
scope, diverse in its targeted audience and accessible to people beyond the academy. People interested in cultural geography, anthropology, folklore, religious studies and Canadian history would reap the most benefit from the text, and the bibliographies following each chapter are extensive and well organized, offering encouragement to look further into the material at hand.

Consisting of eight chapters and a fieldnote-based epilogue, the history of the Inuit in Nunavut starts by describing Nunavut's rise to territorial status. The first chapter, "Inuit and Astronauts," successfully describes how Inuit culture is both rooted in traditional lifeways and embraces both modern technology and lifestyles. McElroy describes a Nunavut Day celebration, which includes Inuit country music and visits from astronauts, as a way to frame the premise of her ethnography. She makes it clear that personal experience is important and is widely incorporated in the book to describe how Inuit deal with sociocultural and political issues in a way that blends together natural landscape and cultures of multiple generations.

The notion of the authenticity of Inuit culture also plays an important role in the text, especially in recognizing the fact that Inuit life has been heavily romanticized by outsiders. In the second chapter, "Early Encounters," European romanticism is brought to the reader's attention in a historical context. McElroy does an excellent job of demonstrating that this romanticism is false; the Inuit lifeways were just as rooted in tradition and variation as any other culture of their era, and embracing new things was not always something detrimental. Such embracing carries on to the third chapter, "Dance from the Heart," which discusses Qallunaat (European) influences on Inuit life with an emphasis on religion, health and authority. Oral history describes how such interactions are met with both fondness and ambivalence, and McElroy does not shy away from including the fact that there were issues with many outside influences.

Up to this point in the text, there is little about McElroy's personal experience in the field, but this changes with the fourth chapter, "Living with the People." Breaking down her fieldwork experience chronologically, we learn of McElroy's quest to understand Inuit life from their perspective; the chapter is unromantic in describing the fact that conditions were not always the best. An emphasis on 
relationships with the locals is also brought to the reader's attention; she saw the families she interacted with as mentors and peers, bringing a personal touch to the ethnography. Such a focus on the individual voice continues in the fifth chapter, "Becoming Townspeople," as McElroy discusses change in the eyes of Nunavut elders and in the memories of those who left their lifestyle to move to towns such as Iqaluit (Frobisher Bay) and Cape Dorset. The relocations are not without criticism, as claims of exploitation, forced family separations and removal from traditional knowledge are demonstrated as being common.

Such a mix of Euro-Canadian and Inuit life resulted in a process of biculturation, which is the core point of the sixth chapter, "Growing Up Biculturally." Through examining life cycles in chronological order, McElroy illustrates that almost all Inuit children were born in a bicultural lifestyle; being born in Montreal or Ottawa (a process treated as standard policy) seemed to frame life that way from the start.

McElroy explains the stages of life in a clear way, explaining social norms and expectations while also emphasizing the adjustments to Euro-Canadian schools, social groups and careers. Such adjustments were often part of relocation, the focus of the seventh chapter, "Relocation and Loss." Many Inuit families were forcibly removed from their communities in the middle of the $20^{\text {th }}$ century, and this has resulted in a change in self-perception and the grieving process. Circumstances such as illness, residential schooling and alcoholism all contributed to such perceptions, and McElroy utilizes a mix of history and oral testimony to describe how such issues, among others, were part of everyday life for many Nunavut residents.

Such issues led to discontentment among the Inuit, eventually leading them to develop their own voice and movements; the eighth and final chapter, "Finding a Political Voice," describes how such a movement formed among the Inuit throughout Canada. Such a voice was vital in the development of Nunavut as a territory, and McElroy utilizes a history of Inuit efforts to contextualize how life in the newest territory is interpreted by elders, who see natural landscapes and traditional lifeways as being important to future generations. The culture is not seen as past, but living, and this is among the most 
important points of the book; identity is rooted in a living traditional culture and will aid in shaping the territory's future.

Such a future is a part of McElroy's epilogue, which consists of notes from a 2006 field session and discusses the rise of youth interest in Inuit lifeways. This rise, combined with resiliency and the continuation of a syncretic culture, is a laudable way to end this ethnography given the fact that the youth are the next generation who might, one day, be the elders providing the testimony. This multi-generational perspective is one of the greatest strengths of the book, demonstrating how all groups are vital to Nunavut culture in unique and fascinating ways. With a focus on such a perspective, a grand theoretical idea of Nunavut culture is unnecessary, and McElroy succeeds in making the Inuit voice the most important voice for the reader to understand. 